\title{
Dada ve Sürrealizmde Eleştirel Bir Yöntem Olarak Oyunsal Retorik
}

Arş. Gör. Dr. Aysel ALVER

Mardin Artuklu Üniversitesi

GSF, Heykel Bölümü

ayselalver@yahoo.com

ORCID: 0000-0002-4163-1074

\begin{abstract}
Öz
Bu çalışmada 19. yüzylıı sonlarından itibaren Avrupa'da sanat alanında oyunsal bir retorik ile gerçekleştirilen eleştirel dil üzerinden değişen temsil anlayışı ve anlatı biçimleri ele alınmıştır. 20. yüzyıl Avangard sanat hareketleri tarafından ortaya konan bu eleştirel yaklaşımlar burada, özellikle sürece öncülük eden Dada ve Sürrealizm akımlarına ait bazı sanat pratikleri üzerinden örneklendirilerek tartışımışır. Sanat alanında biçim ve içerik bağlamında radikal değişimlere neden olan bu eleştirel tutumlar aynı zamanda dilbilim ve göstergebilim alanında ortaya konan tartışmalar kapsamında ele alınmıştır. Avangard sanat hareketlerinin geleneksel anlatı ve temsil biçimlerini eleştirmek amacıyla ortaya koydukları bu eleştirel retoriğe göre dilsel yapının merkezine ironik ve oyunsal bir anlatı yöntemi konulduğu belirtilmiştir. Göstergeler arası özgür bir montaj fikrine dayandırılan bu anlatı yöntemi ise metafor kullanımında özgür bir ilişkisellik ve özdeşlik fikrine dayandırılarak gerçekleştirildiği belirtilmiştir. Öte yandan bu çalışmada, Post-yapısala anlayışın Yapı-sökümcü yaklaşımının bir parçası olarak geliştiği belirtilen bu eleştirel retoriğin aynı zamanda Postmodern sanat anlayışına da kaynaklık ettiği belirtilmiştir.
\end{abstract}

Anahtar Kelimeler: sanat, retorik, oyunsal, metafor, montaj, kolaj

Alver, A. (2020). Dada ve Sürrealizmde Eleştirel Bir Yöntem Olarak Oyunsal Retorik. ARTS: Artuklu Sanat ve Beşeri Bilimler Dergisi, 3, ss. 10-24. 


\title{
Playful Rhetoric As A Critical Method in Dada And Surrealism
}

\begin{abstract}
In this study, the playful rhetoric which was put forward as a critical method in the area of art in Europe as of the late 19th century has been addressed. This rhetoric which was developed by Avant-garde art movements of the 20th century has been discussed via examples particularly on the basis of certain art practices appertaining to Dada and Surrealism movements which spearheaded the process. These critical attitudes which gave rise to radical changes in terms of style and content in the area of art have been analyzed also in the context of discussions set forth in the field of linguistics and semiotics. It has been stated that an ironic and playful narration method was placed at the hearth of linguistic structure as per this critical rhetoric which was proposed by Avant-garde art movements in order to criticize conventional styles of narration and representation. It has been suggested that this narration method which was predicated on the idea of a free intersemiotic montage was executed on the basis of relationality and identity notions which gave freedom to use metaphors. On the other hand, in this study, it has been asserted that this critical rhetoric which was alleged to be building up as part of the Deconstructivist approach of Post-structuralist understanding also gave birth to Post-modern art understanding.
\end{abstract}

Keywords: art, rhetoric, playful, metaphor, montage, collage 


\section{arts $=$}

\section{Gíriş'}

Sanatçılar, tarih boyunca bulundukları dönemin güncel konu ve kavramları etrafında üretimlerde bulunmuşlardır. Bu ortak yönelim, sanatçıların her dönem benzer ifade ve temsil biçimleri geliştirebilmelerine de olanak sağlamıştır. Sanat alanında ortaya konan pratiklerin özellikle bazı dönemler kimi sosyal formasyonlara özgü ideolojik ve kurumsal mercilerin himayesinde şekillendirildiği bilinmektedir. Örneğin Ortaçağda dinin hizmetinde olan sanat, 20. yüzyıla gelinildiğinde küresel kapitalist sistemin ekonomi-politiğinin bir parçası haline gelerek, kimi ideolojileri yaygınlaştırmak için kullanılan etkili bir araca dönüşmüştür. Dolayısıyla tarihsel olarak değerlendirildiğinde, insanın duygu ve duyarlılıklarının kapsayıcı bir edimi olarak sanatla siyaset ontolojik anlamda her zaman farklı düzeylerde bir etkileşim içerisinde olmuşlardır. Hatta bazı dönemler siyasetin doğrudan sanatın konusu haline geldiği veya sanat pratiğinin kendisinin siyasi bir eylem biçimine dönüştürüldüğü örneklere de rastlanır. Dolayısıyla, sanat pratiğinin politik anlamda bir söylemi içerisinde barındırıyor oluşu, toplumsallaşmasının bir gereğidir; tıpkı felsefede de olduğu gibi.

Adorno, sanatın politik bir bağlama sahip olmasının onu doğrudan toplumsal süreçlere müdahale eden bir eyleme dönüştürmediğini belirtir. Adorno, sanatı toplumsal gerçekliğin içinde sınırlı bir bölgede gerçek değerlere sahip örnek bir alan olarak tarif eder. Böylece toplum gerçeğine doğrudan müdahale etmeyerek, varlık alanını toplumsal gerçekliğin tümüyle dışında belirleyen bir model düşüncesine dayandığını belirtir (aktaran Dellaloğlu, 1995 s. 50-51).

20. yüzyıl Avangard Batı sanat hareketleri toplumsal bir muhalefetin parçası olarak eleştirel bir tutum etrafında bir araya gelen şair, yazar, tiyatrocu ve sanatçılardan oluşan kolektif yapılardan oluşmaktaydı. Toplumsal süreçlerin parçası olarak ortaya çıkan bu sanat hareketleri, anlatılarını politik bir söyleme dayandırarak, söylemin kendisini öne çıkaran bir yönelim içerisine girmişlerdir. Birinci Dünya Savaşı sonrasında dünyada değişen ekonomik dengeler ve ortaya çıkan yeni ulus devlet yapıları ile yeni pazar alanlarının oluşması, beraberinde yeni siyasi rejimlerin, toplumsal hareketlerin belirginleşmesini ve İkinci Dünya Savaşı koşullarını oluşturmuştur. Birinci

1 Bu makale Hacettepe Üniversitesi Güzel Sanatlar Enstitüsü Heykel Anasanat Dalında Prof. Turhan Çetin danışmanlığında yürütülen "Sanatta Oyunsallık ve Kurgu" başlıkı Sanatta Yeterlik Sanat Çalışması Raporu'ndan üretilmiştir. 
Dünya Savaşı sonrasında yükselen koloniyel hareketler, derinleşen sınıf ayrılıkları ve sanatın Avrupa'da burjuva sınıfının tekelinde belirli kurumlara hapsedilip bir yatırım aracına dönüşerek metalaşması, dönem sanatçılarının tepkisine yol açmıştır. Sanatçılar, bilimsel-diyalektik tarih anlayışı ekseninde ortaya çıkan toplumsal muhalefetin bir parçası olarak politik söylem ve fikirler etrafında bir araya gelerek, kolektif sanat hareketleri kurmuşlardır. Sanat nesnesinin metalaşması ve fetişleşmesine karşı çıkan bu hareketler arasında ilk tepki, bilindiği gibi bir grup şair ve sanatçıdan oluşan Dada hareketinden gelmiştir. Dada hareketinin savaşa ve piyasa anlayışına dair ortaya koyduğu eleştiriler aynı zamanda Modern dönem sanat anlayışının içerik ve biçim diline de yöneliktir. Söz konusu bu eleştirel dil üzerinden üretilen sanat çalışmalarında görülen retorik değişimi ise özünde metafor kullanımındaki değişime dayanmaktadır. Bu değişim, sanat pratiğinde -miş gibi yapma edimi üzerinden kurulan dile dayalı yeni bir gerçeklik kavrayışıyla ortaya konmuştur. Ancak bu türden bir anlatı biçimi aynı zamanda sanatın ne'liği tartışmalarıyla birlikte devam etmiştir. Bu bağlamda büyük bir dönüşüm yaratan ilk radikal çıkışlar ise bu yeni eleştirel retoriğe dayalı ironik ifade biçimlerinden oluşan sanat pratikleriyle gerçekleştirilmiştir. Sanatın nesnel gündelik gerçeklikle arasındaki mesafeyi de ortadan kaldırmaya yönelik ortaya konan bu eleştirel yaklaşımlar ve yürütülen tartışmalar öte yandan sanatın izleyici ve mekânla ilişkisinde de daha dinamik ve etkileşimli yeni bir süreci başlatmıştır. Tüm bu gelişmelerin yanısıra dönemin Avangard sanat hareketlerinin toplumsal süreçlerle de daha yakından ilgilenmesi bir tesadüf değildir.

İnsan aklını, gerçekliğin ve doğal olanın ötesinde arayan Dadacılar, dünyayı saçma bir savaşa sürükleyen rasyonel aklın karşısında denetimsiz bir akıldışlıkla savunmuşlardır. Teatral bir mizansenle sahneledikleri performansları, politik bir bağlama sahip sert eleştiri anlayışılarıyla Dadacıların itirazı, özünde insan ve ürünlerinin şeyleştirilmesine yönelik, sanat ve edebiyat cephesinden gösterilen bir tepkidir. Dolayısıyla bu noktada ideolojik anlamda belirli bir konjonktüre dayalı bir yönelim söz konusudur. Bu anlayışa göre diyalektik-bilimsel bir gerçeklik üzerinden yorumlanan tarihin birer öznesi olarak tanımlanan bireyin -sanatçının ve izleyicininyeniden doğuşu ilan edilmektedir. Yani var olan gerçekliğe karşı sanat alanından ortaya konan gerçek bir eylemselliğe işaret edilmektedir. Bu anlayış ise tarihsel bir figür olarak kavranan özne fikriyle birleşmektedir. Burada ortaya konan itiraz ise özünde, toplumsal şeyleşmeye karşıdır. 


\section{arts}

Ayrıca, Dada hareketinin sanata getirdiği eleştiriyle biçim, malzeme, içerik ve dil açısından meydana getirdiği yenilik, 1940'lı yıllarda eleştirel bir dilden öte, Postmodern dönemin sanat anlayışına özgü doğal bir retorik haline gelmiştir.

\section{Eleştirel Dillin Oyunsalığı ve Sanatta Değişen Retorik}

Platon'un gerçeğe ulaşmada engel olarak gördüğü retoriğe dayalı anlatı biçimini Aristoteles yeniden yorumlayarak, sadece ikna etmekiçin her yola başvurmak olarak değil, her konuda ikna etmede kullanılmak üzere içeriği değerlendirme becerisi olarak ele almıştır. Retoriği hatip, konu ve muhatap olmak üzere üç temel unsur üzerinden ele alan Aristoteles, Platon' un tersine hitabın gücünü argümanlarına dayandırarak, retoriğin mantık/diyalektik ve felsefe arasında kesin bağlar kuran bir noktada durduğuna dikkat çeker (Altınörs, 2011).

Sanat alanında metafor kullanımının bir parçası olan retorik, öte yandan sanata ir-reel bir değer kazandıran temel bir unsur olup, aynı zamanda kavramsal bağlamın inşası bakımından da önemli bir role sahiptir. Anlamın maddi bir taşıyıcısı olarak sanat nesnesi bir anlatıya sahip olmasıyla dille de doğrudan bir ilişki içindedir. Ancak gündelik doğal dilin ontolojisinden farklı bir ontolojik karaktere sahip olan bu dil, göstergelerarası dolayımlar ve özdeşlik ilişkilerine dayandırımaktadır.

Her tasvir edilen şeyin varlığı aştığını belirten Tunalı, sanat eserini, yani estetik objeyi tabiattan ve reel objeden ayırarak, temsilin varlık alanına işaret eder. Bu ayrımı sanat eserine sanatçı tarafından yüklenen bir ifadenin ve anlamının olmasına bağlamaktadır. Burada estetik varlığın, bir yanıyla gerçeğe dayanan reel bir obje olduğuna, diğer yanıyla da kendisine atfedilen değerlerle bir anlam varlığı olduğuna işaret edilmektedir (aktarımıyla Altınörs, 2011).

Doğal dil ile sanat arasındaki metinsel ve anlamsal ilişkinin ötesinde, özellikle 20. yüzyııın başından itibaren yazı dilinin görsel bir imge olarak sanat alanında sıklıkla kullanıldığı bilinmektedir. Sanat alanında farklı nedenlerle ve farklı biçimlerde kullanılan yazı dilinin özellikle Kübizm'le birlikte, kolaj ve asamblaj tekniği içerisinde kullanıldığı ilk örneklerden, 1960'lı yıllardan itibaren kavramsal sanat anlayışı içerisinde bir çok sanat hareketi tarafından da yaygın bir biçimde kullanıldığı bilinmektedir. 


\section{$\operatorname{arts}=$}

Tunalı, montaj sanatı olarak adlandırdığı bu süreci şu şekilde tarif etmektedir. 20. yüzyıın ortalarında dil alanındaki tartışmalar ve sanat alanında değiş̧en anlatı yapıları, ikonografik veya optik betimleyici anlatımlarının yerine, içerik ile biçim arasında farklı bağlamların kurulduğu göstergelere dayanan temsil anlayışları ve anlatı biçimleri almıştır. Bu dönemle birlikte Tunalı'nın da belirttiği gibi tasvir sanatı mantığı önemini yitirmiş ve nesne kendi görüntüsünün yerini almıştır (2015, s. 131). Asamblaj tekniğiyle hazır nesnelerle gerçekleştirilen enstalasyonlardan oluşan bu yeni anlatı biçimini "montaj" sanatı olarak adlandırılan Tunalı, bu anlayışa yeni göre tasvire dayalı anlatının ise yalancılık olarak sayıldığını ifade etmektedir (2015, s. 132).

Birinci Dünya Savaşı'nda sanata inancını kaybeden bir grup şair ve sanatçı tarafından İsviçre'de kurulan Dada hareketi, burjuva entelektüellerinin tekelinde olduğunu belirttikleri Modern dönem sanatını eleştirmişlerdir. Bu sanat anlayışının yalnızca belirli bir sınıfın ideolojik anlayışının bir parçası olduğunu ve bu sınıfın düşünce biçimiyle hareket ettiğini ifade eden Dadacılar, bu anlayışın gerçeklikle ve hayatla bir ilgisi olmadığını iddia ederler. Sanatın anlamını kaybettiğini belirterek yaptıkları şiir dinletileri ve sergiler gibi etkinliklerle, sanat karşı†ı bir söylem ortaya koyarak, radikal ve ironik bir eleştirel dil kullanmışlardır.

Öte yandan tiyatronun önemine vurgu yapan avangart sanat hareketleri, bu türden bir gösterinin izleyici üzerindeki dönüştürücü gücüne işaret etmişlerdir. Özellikle Dada hareketi Kabare Voltaire'de, sanatı performatif bir dille sahneye çıkararak teatralleştirmiş ve bir tür gösteriye dönüştürmüştür. Böylece Dada hareketi Kübizm'den devraldığı kolaj ve asamblaj teknikleriyle retinal olana yönelik ortaya konan oyunsal dili sahneye taşıyarak ve performatif bir yaklaşımla bir tür gösteriye dönüştürerek, özünde sanat nesnesinin bağlamını ve anlamını genişletmiştir.

Dada'yı bir dünya kabaresi olarak tanımlayan Huelsenbeck, dünyanın da bir Dada kabaresi olduğunu ifade eder. Huelsenbeck bu ifadesiyle izleyicinin teatrelleşen bu sanat gösterilerinin parçası olduğuna dikkat çeker. Dada Manifestosunun 1916' da şiirler, danslar, kostüm ve resimlerle sahnelenmesi onu bir tür gösteriye dönüştürerek öte yandan manifesto sözcüğünü de bir yanıyla eylemleştirilmiş olmasıyla önemli bir başka noktada durmaktadır (e-skop). 


\section{arts}

Modern dönemin ideal-büyük sanat anlatılarına karşı sanata, çocuksu bir tazelik ve yenilikle yaklaşmayı öneren Dada Hareketi, ritmik tekrarlardan oluşan, şiirsel, ironik ve kalıcı olmayan çalışmalarla tepkilerini göstermişlerdir. Kolaj ve asamblaj tekniği ile hazır nesne kullanımına başvuran Dadacılar özellikle sanat alanında hazır-nesnenin kullanımıyla hem sanat nesnesinin tanımını değiştirmişler, hem de gündelik hayat ile sanat arasındaki uçurumu kaldırarak izleyicinin konumlanışına da müdahale etmişlerdir.

Sanatı belirli bir sınıfın tekelindeki kurumsal temsiliyet alanlarının dışına taşıyarak gündelik hayatın bir parçası haline getirmek amacıyla çalışmalarında gündelik hayata ait hazır nesneleri kullanan Dadacılar böylece sanat nesnesinin fetişleştirilmesine yönelik bir eleştiriyi de ortaya koymaktadırlar. Öte yandan geçicilik duygusu üzerinden oluşturulan bu sanat pratikleriyle sanat nesnesi de yeniden tanımlanmaya başlanmıştır. Gündelik hayata ait nesnelerin sanat alanına taşınması, aynı zamanda bu sıradan nesnenin kavramsal bir bağlamla kavuşmasına da işaret etmektedir. Bu durum tıpkı oyunda olduğu gibi, gündelik nesnenin sahip olduğu sıradışılığın keşfini de mümkün kılmıştır. Bu süreçte izleyici de dinamik bir zihinsel katıım ve eleştirel bir yönelim içerisine girebilmiştir.

Gündelik, endüstriyel veya doğadan bir nesnenin bağlamının değiştirilmesiyle başlayan imge üretiminin, sanat pratiğinde oyunun başladığı an olduğunu söylemek mümkündür. Özellikle izleyici ile sanat nesnesi arasında yeni bir ilişki biçiminin gelişmesini de beraberinde getiren bu yeni süreç, zihinsel bağlamda interaktif bir katıımı da ortaya çıkarmaktadır. İzleyici gündelik gerçekliğe ait olan bilindik bir nesneyi yeni bir bağlamda, sanat olanın alanı içerisinde okumaya ve yorumlamaya başlamıştır. Dolayısıyla hem izleyici hem de sanatçı, tıpkı oyundaki gibi, gündelik gerçekliğe ait olan söz konusu nesneyi ona yüklenen rol doğrultusunda ele almak konusunda hemfikirdirler. Bu, özünde sanatın kendi içinde de, sanat alanına özgü bilindik normlara yönelik de bir tür yeni bir varlık düzlemine işaret etmektedir. Bu varlık düzlemi gösteren ile gösterilen arasında kurulan ilişkinin biçiminde, yani retorikte gizlidir. Hazır nesne ile başlayan bu süreç tıpkı bir tahta parçasını oyuncak bir bebek olarak gören bir çocuğun, tahta parçası ile oyuncak bebek düşüncesi arasında kurduğu ilişkinin kesiştiği noktada başlattığı oyun fikri gibidir. Burada gösteren ile gösterilen arasında oluşturulan kesişim alanı, içkin ve heteroitik (düşsel ve kozmik) bir 


\section{arts}

uzamsal alana işaret etmektedir. Tristan Tazara'nın bir protesto ve yıkıcı bir eylem olarak tanımladığı Dada hareketi, mantığın yerle bir edilişi ve özgürlük olarak tarif edilmektedir. "Çarpışan renklerin, zıłların birliğinin, grotesk şeylerin, tutarsızlıkların ifadesi; kısacası yaşamın kendisidir" (Antmen, 2008, s. 122).

Kolaj ve asemblaj gibi tekniklere ağırlık veren, ifadede rastlantısallığı son derece önemseyen, Batılı olmayan kültürlerin 'primitif' ifadelerine ilgi duyan Dadacıların en büyük özelliği, sanat ile yaşam arasındaki sınırları yok etme arzusu ve bununla bağlantılı olarak gelişen sanat karşııı tavırdır. Dada'yı diğer akımlardan ayıran da esas olarak bu özelliğidir. Kolajı Kübizmle, Doğaçlama performansları Fütürizmle, ket vurulmamış doğrudan ifadeye yönelik ilgiyi Dışavurumculuk'la ilişkilendirmek mümkündür ama bu akımların hiçbirinde Dada'nın radikal sanat karşıtlığı yoktur. "Ben"diyen Dışavurumculluk'lara karşı "Biz" diyen, çünkü kollektif bir bilinç oluşturmak isteyen Dadacıların bu "biz"inde ortak bir üslup değil, ortak bir rủh hali vardır. (Antmen, 2008, s. 124)

Antmen'in aktarımıyla, Dada'nın sanat karşıtı tavrının en belirgin ifadesi olan anti-sanat terimini ilk olarak Marcel Duchamp kullanmıştır (Antmen, 2008, s. 124). Antmen, Duchamp'ın sanata getirdiği en büyük yenilik olarak, sanatın alışılagelmiş üretim, sunum ve değerlendirme ölçütlerine ilişkin beklentileri yerle bir ederek, estetik beğeni ölçütlerinin nasıl şekillendiğini sorgulayarak, salt retinal hazzı reddedip, sanatı bir yetenek ve beceri eyleminden, bir düşünme eylemine dönüştürmüş olmasını göstermektedir (2008, s. 124-125). Antmen, 1913 yllından itibaren Bisiklet Tekerleği ile (Görsel 1) başlayan, Şişelik ve 20. yüzyılın en çok tartışılan Çeşme (Görsel 2) gibi çalışmalarıyla devam ederek, Duchamp'ın, Kübist kolaj geleneğini devam ettirdiğini ifade etmektedir. Antmen' in yorumuyla Duchamp yaşamdan alınan bir kesiti yapıtın içine entegre etmemiş, sıradan bir nesneyi doğrudan sanat yapıtı olarak önermiştir. Antmen'in aktarımıyla, Amerikalı eleştirmen Harold Rosenberg, sanatta hazır-nesne kullanımıyla nesnenin bir tür kaygı nesnesine dönüştürüldüğünü belirtmektedir (Rosenberg 'den aktaran Antmen, 2008, s. 124-125). 


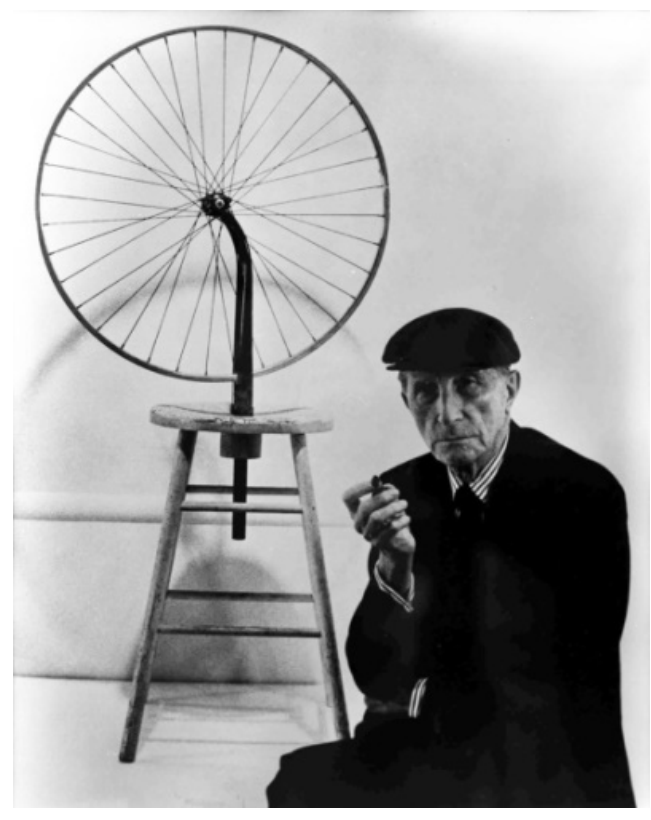

Görsel 1. Marcel Duchamp, "Rove de Bycyclette" (Bisiklet Tekerleği), 1914, asamblaj $129,5 \times 63,5 \times 41,9 \mathrm{~cm}$, bit.ly/340784h

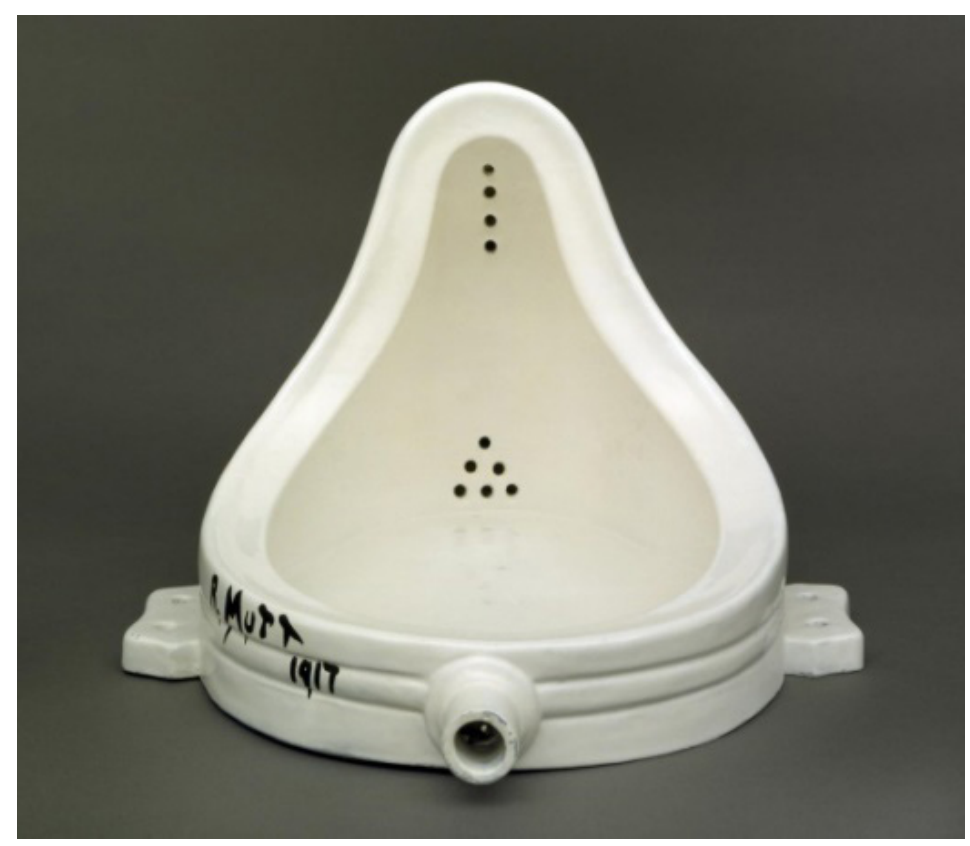

Görsel 2. Marcel Duchamp, "Fontaine" (Çeşme), 1917, hazır nesne, 1917, 61×36x48 cm, bit. ly/2DYQCa9

Aynı yıllarda Sürrealistlerin Paris'te çıkardığı bir derginin önsözünde, insana tüm özgürlük haklarını sadece rüyaların tanıdığı beyan edilerek, rüyaların gündelik gerçekliğin telafisi ya da ondan kaçış olmanın ötesinde, zihni farklı bir gerçeklik 
yaratması için özgür bırakmanın yolunu açıyor olduğuna işaret edilir. André Breton tarafından kişinin düşüncelerinin en saf halindeki otomatizmi olarak nitelendirilen Sürrealizm kelimesini, usa vurulmayan, hızlı, apansız, hatta fevri yaratıcılığın; rastlantıya yer açan oyunculuğun; rüya âleminden ve bilinç dışından beslenen, aklın hükmünü sarsan, arzuyu egemen kılan yeni bir gerçekliğin peşinde olmak olarak tarif edilmektedir (Artun, 2014, s. 11-12).

\begin{abstract}
Nesnelerin yalnızca imgeleri ya da temsilleri değil, kendileri de sürrealisł duyarlııkta karşlık buluyordu. Başta Duchamp'ın hazır- nesnesi olmak üzere, Sürrealistlerin Dada'dan devraldıkları bir başka usül de, geleneksel sanat kategorileri dışında kalan bulunmuş nesnelerle asamblajlar, 'heykeller' oluşturmaktı. Sürrealistler gündelik hayatta kullanılan sıradan nesnelerdeki sıradışılığı keşfettiler (Artun, 2014, s. 15).
\end{abstract}

Bu dönemden itibaren gerçekleştirmiş çalışmalarda dikkat çeken bir başka unsur ise Kübizm ve Dada'dan sonra dilsel öğelere resimsel bir dil bağlamı içerisinde, imgesel bir kolaj yöntemiyle yer verilmiş olmasıdır. 20. yüzyılın ortalarında gerçekleştirilen dilbilimsel çalışmalardan etkilenen bazı sürrealist sanatçılar ve Sanat ve Dil Grubu gibi kimi sanat hareketleri, metin dilini görsel bir imge olarak anlamı ve düşünceyi güçlendirmek için kullanmışlardır. Bu bağlamda özellikle yaşadığı dönemde Saussure ve Wittgenstein gibi dil alanında çalışmalar gerçekleştirmiş olan düşünürlerden etkilenen René Magritte de sanatın bir iletişim aracı olduğu düşüncesini benimseyenlerdendir. Bu düşüncesinden hareketle çalışmalar gerçekleştiren doğalcı Sürrealist bir sanatçı olarak tarif edilen Magritte (Norbert, 2004, s. 181), 1930 tarihli İmgelerin ihaneti adlı serisinde görsel gösterge ile metinsel dili bir arada kullanmıştır. Çalışmasında sözcük, sözcüğün temsil ettiği kavram ve obje arasındaki ilişkiyi, gösteren ve gösterilen arasındaki ilişki bağlamında ele aldığı bir tartışmayla, temsil ve gerçeklik ilişkisini üç ayrı biçim üzerinden irdelemiştir: Objeler, onların görsel temsilleri ve dilsel temsilleri arasındaki ilişkidir. Magritte bu tartışmayı özünde kavramlar ve onların gösterenleri arasındaki ilişkide, göstergebilimsel bir tartışma kapsamında yürütmüştür. 1929' da gerçekleştirdiği Sözcüklerin Kullanışı isimli bu çalışmasında görülen gerçekçi bir pipo imgesi üzerine yazılmış olan Ceci n'est pas une pipe yani Bu bir pipo değildir (Görsel 3) ifadesi ile göstergenin kendisi ve ifadesi arasında bir gerilim yaratarak oyunsal bir dille eleştirel bir tavır ortaya koymaktadır. 


\section{$\operatorname{arts}=$}

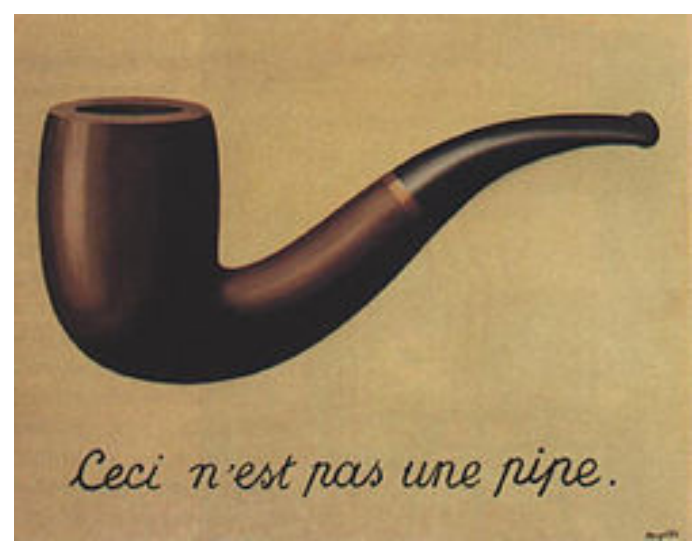

Görsel 3. René Magritte, "La Trahison des Images - Ceci N'est Pas Une Pipe" (İmgelerin ihaneti - Bu Bir Pipo Değildir), tuval üzerine yağlı boya, 1928-29, 64,5x94cm, Los Angeles

County Sanat Müzesi, bit.ly/2Lvm IFp

Magritte, göstergeyi oluşturan unsurlar arasındaki ilişkinin heteroklit yapısına yani, kültürel ve toplumsal süreçlere bağlı, rastlantısal, keyfi uzlaşımsallıklara dayalı olduğu görüşünü destekler. Bu heteroklit yapı aynı zamanda oyun dilinin de temel davranışsal yapısının bir özelliğidir. Öte yandan Lynton'un aktarımına göre Magritte'in bu resminde, aynı zamanda üzerinde yazılan notla değillediği görsel imge, gerçek bir pipodansa pipo imgesinin çok daha gerçek olduğu önermesini ortaya koymaktadır (2004, s. 181). "Temsiller köklerini, anlamlarını aldıkları bir dünya içine salmazlar; kendilerine özgü olan ve iç sinirleri anlam yerine geçen bir mekâna doğru kendiliklerinden açılırlar. Ve dil burada, temsilin kendiliğinden oluşturduğu açıklıktadır" (Foucault, 2015, s. 128). Foucault, temsil etmenin, tecrübe etmek, göze görünür bir aktarım yaratmak, düşünceyi bedenin dış kanadı üzerinde, tamlığı içinde yeniden üretebilen maddi bir ikiz imal etmek anlamına geldiğini belirtir: "(...) dil, düşünceyi tıpkı düşüncenin kendi kendini temsil ettiği gibi temsil etmektedir" (Foucault, 2015, s. 127).

Magritte'nin Imgelerin Ihaneti serisinden bir başka çalışması olan Düşlerin Anahtarı bu bağlamda önemli örnekler arasında yer alır. 1935 yılında gerçekleştirdiği bu çalışmasında Magritte, dört ayrı nesnenin görsel imgelerle birlikte bunları tanımlayan metinsel ifadelere yer vermiştir. Görsel temsillerden farklı olan metinsel ifadelerden yalnızca biri doğru olarak kullanılmıştır. Örneğin, at imgesinin altına the door (kapı), saatin altına the wind (rüzgar), sürahinin altına the bird (kuş), valizin altında the valise (valiz) belirtilmiştir. Göstergeler arasındaki ilişkinin biçiminde bağlamın ve söylemin önem kazandığı görüşlerinin ortaya konduğu bu dönemde 


\section{arts $=$}

Magritte' nin bu şaşırtmalı ve algıyla oynadığı çalışmasıyla ortaya koyduğu oyunsal dil, sanatta imgelerin ve temsillerinin anlam ve bağlam üzerinden istenildiği gibi kullanılabileceği düşüncesini desteklemektedir. Dolayısıyla göstergeler arasındaki sabitlik ilişkisinin reddinin söz konusu olduğu Magritte'in bu çalışmasında anlatının merkezine oyunun konduğu düşünce yapısı desteklenmektedir. Derrida'nın da dile getirdiği gibi, metinsel ifade ile objeler, imgeler ya da kavramlar gerçekte asla aynı şey olamazlar ve anlam tek bir göstergeyle sabitlenemezdir (Sarup, 2010, s. 40-41).

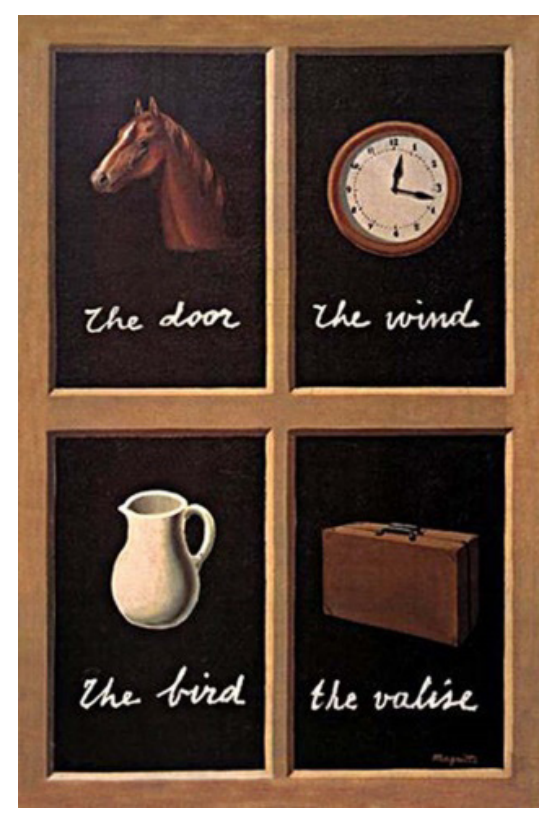

Görsel 4. René Magritte," La Clef des Sognes" (Düşlerin Anahtarı), tual üzerine yağlı boya, 1935, 41x27 cm, Münih, özel koleksiyon, bit.ly/2OYRoKW

Başlangıçta şiirden yola çıkan Sürrealisler, tıpkı herkesin artık şiir yazabileceği fikri gibi artık herkesin resim de yapabileceği fikrini de ortaya koyarlar. Bunu da bilinen geleneksel resim dilini değiştirerek, bu bağlamda bir tartışmayı başlatarak ve kolajı ön plana çıkararak gerçekleştirmeyi denemişlerdir. Bu anlamda Sürrealist kolajın en önemli ismi olan Marx Ernest, Artun'un aktarımıyla, fotoğraf parçaları, çizim ve resim kullanarak yeni ve fantastik gerçeklikler yaratır (Görsel 5-6): "Onun fragmanları tam anlamıyla yerlerinden ederek, birbirleriyle ilgisi olmayan parçalarla başta ait olduklarından farklı gerçeklikleri temsil ettiğini dile getirir" (2014, s. 14). Ernest, sürrealist kolajın işleyişini şu şekilde tarif etmektedir: "görünüşłe ilişkisiz iki gerçekliğin, hiç olmadık bir düzlemde eşleşmesi "(Artun, 2014, s. 14). 


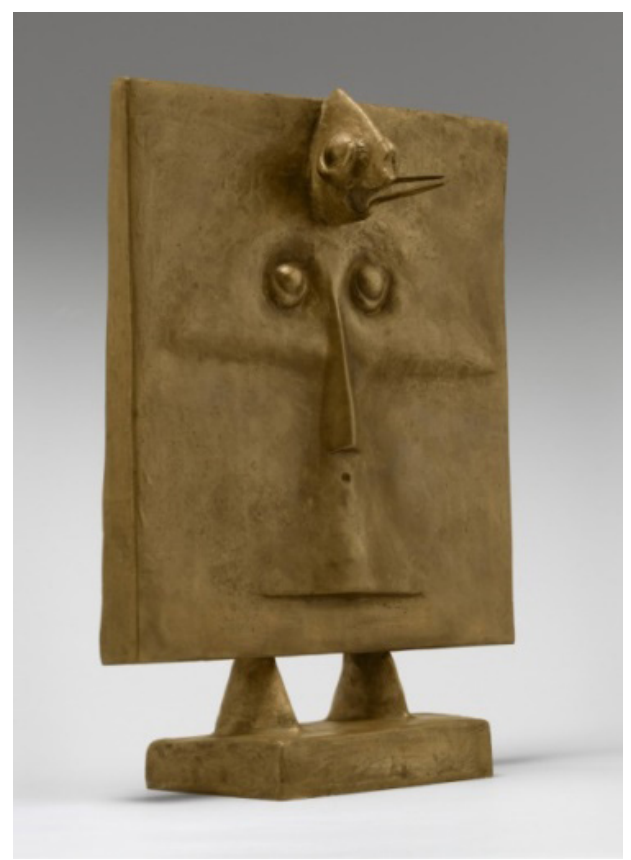

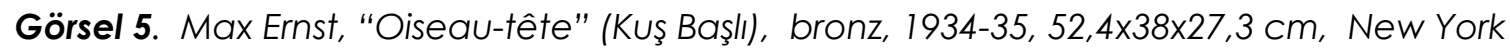
Modern Snat Müzesi, bit.ly/2QHsBdSO

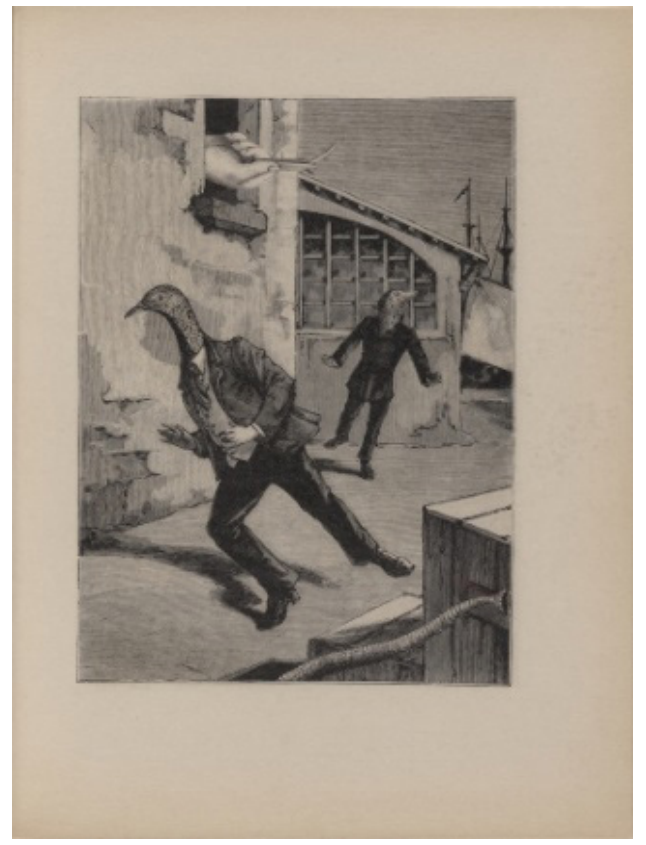

Görsel 6. Max Ernst, "Oedipus" Sayı IV'den bir sayfa, "Une Semaine de bonté ou les sept éléments capitaux," (İyilik dolu bir hafta ya da yedi temel element), 1933-34, yayınlanma 1934, 27x20,5 cm, bit.ly/2DTG4JA 


\section{$\operatorname{arts}=$}

Ernest, burada Lautréamont'un Sürrealistlerce sık sık yenilenen dizesine atıfta bulunmaktadır: "Bir dikiş makinesi ile bir şemsiyenin bir teşhir masası üzerinde tesadüfen buluşması kadar güzel" (Artun, 2014, s. 15). Sanatçı, bu bir araya gelişi, yani kolajın işleyişini, aklın ilişkilendirmekte zorlanacağı denli uzak ve farklı gerçeklikleri özgür bırakılan arzunun bir araya getirilmesi şeklinde tarif etmektedir.

Dada hareketinin ve Sürreailist akımın kimi sanatçıları, geleneksel resim ve heykel diline özgü temsil anlayışını değiştirmeye yönelik ortaya koydukları çalışmalarla, sanat alanında nesnenin ilk kez kendisini temsil ettiği ve gündelik işlevine yabancılaştırıldığı bir anlatıya baş vurarak aynı zamanda yeni bir temsil anlayışının doğmasına da öncülük etmişlerdir. Absürt ve ironik anlatının parçası olan bu ifade biçimleri göstergeler arasında özgür ilişkiselliklerin kurulabilmesi fikri, yani post-yapısalcı anlayışla gerçekleştirilmektedir. Gösterilen ile gösterenin farklı şeyler olarak ele alındığı ve göstergeler arası ilişkide sabit bir anlam ilişkisinin aranmadığı bu anlayışa göre anlatı yapıları içerisinde bağlam ön plana çıkarılmıştır. Böylece sanatta kavramsal alanın inşası gerçekleştirilmiştir.

\section{SONUÇ}

20. yüzyıl Batı sanatında, politik anlamda eleştirel bir anlayışla yola çıkan Avangard sanathareketleri, sanatile gündelik hayat arasında mesafe oluşturan temsil biçimlerini ve sanat nesnesinin fetişleştirlmesini eleştirerek sanatın ne'liği tartışmalarını başlatmışlardır. Sanat tarihsel anlamda büyük bir kıııma yaratan bu eleştirel dilin temelini oluşturan düşünce ise aynı dönemde dilbilimciler tarafından ortaya konan dilsel ve göstergebilimsel yeni yaklaşımlardır. Görsel bir dil üzerine inşa edilen sanatta bağlam tartışmalarında, dilsel yapının merkezine konulan oyunsal anlatı yöntemiyle göstergebilim alanında geliştirilen oyun kuramı, sanat pratiklerinde retoriğin büyük bir dönüşüme uğramasına neden olmuştur. Modern dönemin Yapısalcı dil anlayışına karşı Yapı-sökümcü anlayıştan beslenen bu yeni retorik, sanat aracılığıyla ideal anlama ulaşmak için metafor kullanımında ve bağlamın oluşturulmasında yeni bir gerçeklik ve temsiliyet biçimi oluşturmuştur. Bu bağlamda göstergeler arası anlam ilişkisinde doğrudan bir mantık ilişkisine dayanmayan, serbest bir montaj fikri ortaya çıkmıştır. Modernizmi oluşturan dinamiklerin sanat alanında ortaya çıkardığı 


\section{arts}

Avangard hareketlerden Dada'nın öncülüğünde gelişen bu yeni kavrayış, 1940'lı ylllardan itibaren dünyada etkisini gösteren Postmodern düşüncenin gelişmesine zemin hazırlayan sürecin de bir parçası olmuştur. Zira sanat alanında hazır nesne kullanımı ve özgür montaj fikrine dayalı kolaj, fotomontaj ve asamblaj tekniğiyle gerçekleştirilen çalışmalar ve dil'in sanat alanında farklı biçimlerde kullanımı aynı zamanda Postmodern dönem sanatının kavramsal zeminini oluşturmaktadır.

\section{KAYNAKÇA}

Altınörs, A. (201 1). Platon lle Aristoteles'in Retorik. Ekev Akademi Dergisi yll: 2015 sayl: $49,81-93$

Antmen, A. (2008). 20. Yüzyıl Batı Sanatında Akımlar. İstanbul: Sel.

Artun, N. A. (2014). Sürrealizm Mimarlık Mekan Sanatı. İstanbul: İletişim.

Dellaloğlu, Besim F. (1995). Frankfurt Okulu'nda Sanat ve Toplum, İstanbul: Bağlam.

e-skop (2016, 16 Nisan). Dadanın 100. Yill: Tristan Tzara ve Dada Manifestosu. https://www.e-skop.com/skopbulten/dadanin-100-yili-tristan-tzara-ve-dadamanifestosu/2915. Erişim Tarihi: 15 Kasım 2019

Foucault, M. (2015). Kelimeler ve Şeyler. Ankara: İmge Kitabevi.

Gadamer, H. G. (2008). Hakikat ve Yöntem. İstanbul: Paradigma.

Lynton, N. (2004). Modern Sanatın Öyküsü (Ç. S. Öziş, C. Çapan). İstanbul: Remzi Kitabevi.

Sarup, M. (2010). Post-yapısalcıllk ve Postmodernizm (Ç. A. Baki Güçlü). İstanbul: Kırk gece

Tunalı, İ. (2015). Çağdaş Sanat Felsefesi. İstanbul: Remzi Kitabevi.

e-skop. https://www.e-skop.com/skopbulten/dadanin-100-yili-tristan-tzara-vedada-manifestosu/2915 